\title{
METHODS OF UPBRINGING IN THE FAMILY AS AN AREA OF FORMING THE UPBRINGING AWARENESS OF PARENTS ON THE EXAMPLE OF THE FUNCTIONING OF PROFESSIONAL FOSTER FAMILIES IN SZCZECIN
}

\author{
Urszula Kazubowska \\ University of Szczecin, Department of Humanities, Poland
}

\begin{abstract}
When implementing educational and socialization processes in the family, each parent uses specific educational methods. Methods of family upbringing are considered to be systematic ways of coexistence and coexistence of everyday life situations of the educator with the pupil in a direct or indirect context marked by family axiology. Family upbringing methods always have an awareness dimension. Family educational activity involves the use of various upbringing methods, selected appropriately for the adopted purpose of upbringing on the basis of a thorough knowledge of the child's mental development properties and in accordance with existing pedagogical knowledge. The aim of the research was to learn methods of parenting preferred in professional foster families in Szczecin. The canon of upbringing methods used by foster parents towards children entrusted to them was sought. The research consisted of three stages: theoretical and methodological conceptualization of research issues, pilot studies and actual research. The empirical material obtained was subjected to quantitative and qualitative analysis along with the desire to make a holistic diagnosis of the family. The upbringing methods most often chosen by foster parents include: the method of direct influence with its various implementation options (modeling, giving children educational tasks, persuasion). Equally often, foster parents used the method of adequate reward and punishment, a method of personal influence and a method of managing self-development (especially towards older children). Generally, the preferred methods of upbringing in professional foster families have a positive dimension and in a constructive way influence the optimal way of exercising upbringing and socialization interactions with children raised in family custody. Analyzing the results of research on the obtained data, the following regularity can be seen. The more positive upbringing methods are appropriate in professional foster families, the higher the level of involvement in family education processes saturated with axiology. What's more, the use of positive methods of education in a foster family directly contributes to raising their educational awareness and optimization of various activities towards children in the family.
\end{abstract}

Keywords: parenting methods, rewards and punishments in the family, parental attitude, parenting styles, parental involvement, parents' upbringing awareness. 
Kazubowska, 2020. Methods of Upbringing in the Family as an Area of Forming the Upbringing Awareness of Parents on the Example of the Functioning of Professional Foster Families in Szczecin

\section{Introduction}

Family upbringing is an important subject of reflection and pedagogical research, but it is also noticed in other fields of science.

As a process, family upbringing is fulfilled primarily through a strong personal bond between parents and children, expressed, among other things, in responsibility for others; in mutual meetings, in relationships imbued with love, care, wisdom and experiences of the elders. The conditions and atmosphere created by the family as a unique community, strengthens the process of multidimensional family education and optimizes the development process of the young person and all its members. It is significant that each family upbringing process is marked by a specific axiology determined by the parents (Izdebska, 2003, pp. 73-74; Kazubowska, 2010; Kazubowska, 2017, pp. 37-54; Czerny, 1998; Czerwińska-Jasiewicz, 2015, pp. 20-23).

Attitudes towards children integrally adopted by their parents are related to specific axiology. Maria Ziemska by parental attitudes understands the tendency to behave in a specific way in relation to the child. According to the author, parental attitude consists of the following components: mental (verbal view of the child), emotional (expression of parents' statements and actions), actions (active behavior of parents towards children) (Ziemska, 1973, p. 32). Ziemska put the attitudes in two categories, distinguishing positive and negative attitudes, which can be described as favorable and unfavorable for educational reasons. Positive attitudes included: acceptance of the child, interaction with the child, giving the child reasonable freedom and recognition of the child's rights. Negatives, on the other hand, include: rejection, avoidance, excessive protection and an overly demanding attitude. A child accepted by parents is capable of lasting emotional ties and expressing feelings, is empathic and easily enters into social roles. In an attitude of cooperation, the child undertakes various activities, cooperates with others, and is also able to look after other people's property. An attitude of rational freedom allows the child to easily adapt to new situations, take on various tasks and bring them to the end. Parents presenting an attitude of recognition of children's rights give them the opportunity to take independent initiatives with the awareness of respecting certain family rights and rules. A child rejected by parents is aggressive, quarrelsome, lying, exhibits antisocial behavior and inhibits the development of higher feelings. Avoiding attitude towards a child is manifested by avoiding contact with him, which causes emotional instability, an antagonistic attitude to the environment, entering into conflicts and a lack of perseverance and concentration. The child of excessively demanding parents is characterized by a lack of faith in their own strength, fearfulness, uncertainty, difficulties in adapting to the new environment, or a lack of ability to concentrate. However, the child excessively protected by 
parents is passive, does not show initiative, lacks independence, and is infantile emotionally and socially. It can also be bold, conceited, selfish and overconfident with overstated self-esteem (Ziemska, 1973, pp. 66-69).

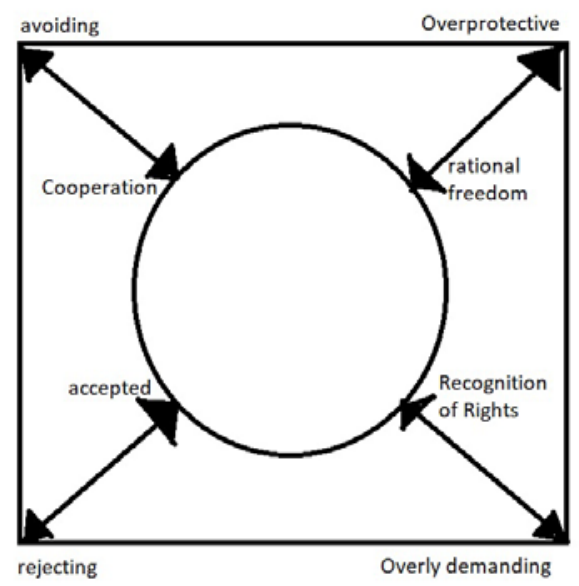

Figure 1 Model of parental attitudes according to Maria Ziemska (1973)

A slightly more extensive typology of parental attitudes was proposed by Schaffer. He distinguished four pairs of polar opposing attitudes: indulgence austerity; tolerance - no tolerance; heat - cold; addiction - separation (Schaffer, 2006).

There is a direct relationship between the parents' attitude towards the child and the appropriate parenting methods. The method of upbringing is a systematic method of behavior of the educator, aimed at causing the charge to engage in such activity (own activity) which is able to lead to the desired changes in their personality (Okoń, 19955, p. 170). Family upbringing methods are a specific way for parents to deal with children in family and non-family life, creating parenting conditions and situations. Their goal is to cause positive child activity and changes in mental disposition and behavior (Cudak, 2001, p. 134).

The literature on the subject presents numerous approaches to the classification of educational methods. The reason for this may be, among others the fact that the authors of individual classifications are based on different theoretical assumptions functioning within social sciences. Łobocki and Konarzewski present the following approaches to the divisions of upbringing methods:

1) individual methods (persuasion, modeling, task method as well as rewarding and punishment) and group methods (organization of team and local government activities and cooperation of students);

2) methods of direct (explaining, persuading, suggestion, persuasion, punishment and reward methods, conversation) and indirect 
Kazubowska, 2020. Methods of Upbringing in the Family as an Area of Forming the Upbringing Awareness of Parents on the Example of the Functioning of Professional Foster Families in Szczecin

(organizing the multilateral activities of the charge in the social environment) educational impact;

3) methods of personal, situational and social influence as well as methods of managing self-education;

4) structural and situational methods. Each of the methods of upbringing is devoid of universal character and complements each other, creating a whole (Lobocki, 2003; Konarzewski, 1982; Sikora, 2010). In relation to upbringing in the family, Grochociński specifically points to two types of methods: direct and indirect impact. Methods of indirect educational impact consist in deliberately organizing the child's conditions and way of life so that his experiences, reactions and experience gained bring him closer to educational purposes, contributing to the proper development of personality. Methods of direct educational impact are generally those that are implemented during direct contact with the charge. The method of persuasion is a special type of educational influence in the family. In family life, conversation can be an example of this. Family conversation is characterized by mutual understanding, trust and faith in the sense of stimulating the interlocutor to be active. When analyzing family upbringing methods, it is also worth paying attention to methods of rewarding and punishing childcare. Educational reward is based on satisfying specific motivations of the child - award as a result of manifesting the desired behaviorally behaviors and constructive forms of activity. On the other hand, the method of punishment is a way of educational impact by means of deliberately used punishments to prevent children from repeating behaviors incompatible with generally applicable norms and values (Frączak \& Lulek, 2010). The use of a variety of educational methods in the family allows for effective interaction of parents with children and young people, which in total can lead to their optimal development, while the parents themselves can increase the level of their educational awareness.

\section{Methodological basis of research}

Research for the purposes of this publication was conducted in a family form of foster care, i.e. in professional foster families operating in the city of Szczecin, West Pomeranian Voivodeship (Poland). They were implemented as part of the project "Foster family - a chance for a better future for the child" affiliated at the Department of Social Pedagogy of the Institute of Pedagogy, Faculty of Social Sciences of the University of Szczecin in 2014-2019. 
Szczecin is a city with poviat status, the capital and largest city of the West Pomeranian Voivodeship. It is the third largest city in Poland $\left(300.55 \mathrm{~km}^{2}\right)$ and the seventh largest city in Poland in terms of population. Like the entire Zachodniopomorskie Voivodship, it faces many social problems such as: a high rate of care needs for various social groups, an equally high percentage of extramarital births, or the level of infant mortality. A disturbing phenomenon stigmatizing Szczecin and the West Pomeranian Voivodeship is also a significant divorce and separation rate or a huge number of children in foster and institutional care. Euro-orphanhood, unemployment, homelessness, multidimensional social helplessness, crime, a sense of alienation and disintegration of residents and the accompanying process of social anomaly are also important problems in and around Szczecin. In recent years, there has also been a phenomenon of the influx of people living in Ukraine, staying in Western Pomerania for profit. Being deeply aware of the complexity of the abovementioned phenomena and social problems, research was conducted on the functioning of foster professional families operating in the city of Szczecin.

The research consisted of three stages. First it was theoretical and methodological conceptualization of research issues, then pilot studies were conducted in five professional foster families in the city of Szczecin. Only after correcting the adopted methodological assumptions after the pilot studies were the actual tests carried out.

Among the surveyed foster professional families were: 9 professional families, 3 specialized professional families, 16 professional families performing the functions of family emergency. In total, 28 foster families with 182 children were examined. Coordinators of family custody in the number of 6 people as well as 6 social workers working in the city of Szczecin in the Municipal Family Support Center in Szczecin and 6 family assistants were also surveyed. For the purposes of this article, upbringing methods used in professional foster families for children in this form of foster care have been analyzed (due to the editorial requirements given). The analysis of foster parenting methods used by parents was considered through the prism of the concept of family epistemology of Ludwik von Bartalanffy, whose strong supporter in Polish psycholopedic literature is Ryszard Praszkier (Praszkier, 1992, pp. 37-61; von Bartalanffy, 1984).

Triangulation of research methods and techniques was used in the research, because the diagnostic survey method with the qualitative dimension of the case study was used. The use of triangulation methods gives the opportunity to obtain a richer material and a broader interpretative spectrum of the studied problem. As part of the diagnostic survey, a survey was used for foster care coordinators, social workers, and family assistants. However, as part of the case study, an indepth qualitative interview with foster parents was used in professional foster 
Kazubowska, 2020. Methods of Upbringing in the Family as an Area of Forming the Upbringing Awareness of Parents on the Example of the Functioning of Professional Foster Families in Szczecin

families from which I gained a broad spectrum of knowledge about the functioning of their family and the creation of educational, socialization and educational processes for children temporarily entrusted to them. As part of exploring the specifics of the processes implemented in foster families, the focus was also on parenting methods used for children residing in them. The material obtained through the interview was supplemented with the technique of direct observation of family members, which allowed to deepen knowledge about the ways of implementing educational, socialization and educational processes in the examined foster families. The empirical material obtained was subjected to in-depth quantitative and qualitative analysis along with the desire to make a holistic diagnosis of families. When characterizing the methods of upbringing used by foster parents in professional foster families operating in the city of Szczecin and their impact on the process of shaping family upbringing, socioeducational and educational processes directed at children residing in them, one cannot ignore ethical issues. The family and the study of its holistic functioning have always belonged and still belong to areas marked by ethical dilemmas. The family environment as the first and most important in human life, the educational environment is a unique research area of a sensitive nature. This socalled a soft area of research requiring the researcher to be reflective, deep in reflection and interpretative multidimensionality, narrative family life. When conducting research in professional foster families, some ethical problems can be encountered. One of them is the fear of the parents surveyed or their preferred parenting methods will allow them to create optimal conditions for the multifaceted development of children entrusted to them. Another area of ethical dilemma in the conducted research was the awareness of the different specific methods of parenting favored by the examined foster parents and the methods recognized by the biological parents of children placed in family foster care. Analyzing the problem of upbringing methods used by foster parents in the context of their upbringing, socialization and education processes towards children entrusted to them, evaluation was avoided, while evaluation was aimed at subjecting the obtained data to multidimensional, objective analysis aimed at creating a model of effective reintegration work with biological families of children residing in family forms of foster care.

\section{Family upbringing methods as an area of forming parents' upbringing awareness in the light of own research Family upbringing methods - outline of the problem}

In the introduction, the definition of the upbringing method has already been discussed and their classification has been listed. It is worth returning to the issue of family upbringing, focusing on particularly useful methods that 
parents can use to implement family upbringing, socialization and education processes towards children. First of all, the methods based on direct influence are important, among them the modeling method, setting up educational tasks, verbal methods of educational impacts as well as the method of rewarding and punishing upbringing. The modeling method is based on giving children and youth patterns and role models and identification. This method is also referred to as the method of acting by our own example or the method of setting a good example. Sometimes it is recognized as learning by observation, substitute learning, learning by imitation or "educational contagion". Imitation consists in mapping the child's observed external behavior while identification is a higher level of mapping. It is about mapping internal states, i.e. motives, beliefs, ways of assessment and evaluation. All mapping processes can be referred to as modeling. In the modeling method, it is important that the child-subject wants to become similar to this model (parent-guardian), shapes his personality in his image, imitating him in forming thoughts, verbalizing views and when speaking about the surrounding world, in social behavior, in daily concrete actions.

In addition to modeling in the process of family upbringing and socialization, the method of posing educational tasks is equally important. The essence of this method is to run your own activity by directing commands to it. It involves entrusting children and young people with specific tasks to perform, which in turn is expected to lead to achieving desired changes in their attitudes and behavior, as well as enriching their knowledge and experience in many areas of human activity. Educational tasks can be divided according to educational content, structure and functions. Taking into account the content, you can even ask tasks related to different daily activities of the child, e.g. the task - "cover the table" or "clean your toys". From a structural point of view, educational tasks can be simple and complex, clear and unclear. However, due to the educational functions, we can distinguish tasks whose goal is to bring about a change in the charge's knowledge structure, develop his adaptability and lead to a change in the attitude of the charge.

Another educational method used in the family is persuasion, which is a kind of verbal influence on the moral and social awareness of children and young people. The essence of persuasion is to translate, explain to the child moral norms and principles, errors in his behavior and other people by referring to broad argumentation. The purpose of persuasion in family upbringing is to bring about changes, beliefs and attitudes of the individual or to enrich their knowledge resources. Thanks to it, pupils (children) learn to distinguish well from evil, find the sense of action, and shape their own system of values. In addition, in persuasion, the individual is stimulated to internal activity by evoking a specific experience of a given problem. A great example of persuasive influence in family education is conversation. The effectiveness of persuasion as 
Kazubowska, 2020. Methods of Upbringing in the Family as an Area of Forming the Upbringing Awareness of Parents on the Example of the Functioning of Professional Foster Families in Szczecin

a method of family upbringing increases when we combine it with other methods, such as modeling, moving specific patterns and patterns to the child, or with the method of raising educational tasks, thus activating the child's own activity and stimulating continuous development.

One of the most effective methods of family upbringing is the method of educational reward. The award is defined as a positive situation, sought by the body, because it is accompanied by a pleasant emotional state, and educational reward consists in satisfying specific motivations of the charge (child) as a result of manifesting desirable upbringing and constructive forms of activity. Properly used rewarding method has two functions: as a result of its use, children learn about the implementation of specific instructions in accordance with the expectations of adults, as well as praise and awards granted under this method become a motivating factor for socially and morally desirable behaviors. There are two types of educational nations: internal and external rewards. Internal rewards are inherent in the activities of man, provide him with pleasure and relate to what he does with passion. On the other hand, external rewards are gratification for displaying specific forms of behavior. The method of educational reward is most often associated with external reward, which aims to bring about internal reward in a timely manner, i.e. achieving internal satisfaction without external reinforcement. Educational awards include: symbolic awards (expressing approval, congratulations, praise); honorary awards (assigning specific functions, tasks, privileges and honorary dignities to children), material awards (giving gifts, books, toys and other things) constituting the end of a certain stage of the child's activities and being a mobilization for further activity (Paszkiewicz 2001). In family educational processes, rewarding is always accompanied by educational punishment. Punishment is defined as providing an unpleasant stimulus (e.g. reprimand) or removing a pleasant stimulus (i.e. prohibiting watching TV or playing) after an inappropriate reaction of the subject. According to Lobocki, the method of punishment is a way of educational impact through the use of deliberately used punishments to prevent children from repeating behaviors incompatible with generally applicable norms and values. There are two types of punishment: external and internal. External punishments are punishments whose source is outside the individual and is associated with the awareness of responsibility for manifested behavior before other people. On the other hand, internal punishments are manifested in the form of remorse that provoke a person to reflect on manifested behavior towards people around them. Educational punishment of an external nature always tends to internal punishment, i.e. the child's (pupil's) awareness of the harmfulness of bad behavior towards other people is shaped, and as a consequence punishment is to change the behavior of the pupil (Kazubowska, 2017). 
Forms of educational punishment include: verbal disapproval of a child's behavior in the form of a warning or reprimand; thwarting the motives of the juvenile from which the wrong act resulted; limitation or deprivation of rights (privileges, functions) adequate to the child's age and development level; obligation to compensate for the damage caused, e.g. repairing damaged item from your pocket money; an obligation to familiarize with the consequences of misconduct (this type of punishment applies especially to young children who still have problems predicting the consequences of their actions); symbolic punishments, involving deprivation of certain honorary rights (they are effective when they are preceded by intensive educational work exposing the rank of symbols in human life); natural punishments, which are an inevitable consequence of improper behavior of the charge (through their own experience the child discovers the unprofitability of proceedings contrary to applicable family norms) (Łobocki, 2004; Ziółkowska, 2005; Jundził, 1986).

In carrying out educational processes in the family, parents sometimes apply non-pedagogical punishments, which include: insulting the child, ridiculing him, humiliating him, depriving him of what he has rights to, regardless of behavior or the use of physical and corporal punishment. These punishments lead to the breaking of the bond between parents and children, a desire for revenge, a sense of shame, regret and inferiority. Hence, nonpedagogical punishments should be reduced or completely leveled from familyrearing processes. If you already use them, you should be aware of their indirect dimension and ineffectiveness. When creating educational processes in the family, parents should skillfully combine reward with punishment, according to the child's age, development and life experiences of the child (especially in family forms of foster care).

Family upbringing methods are closely related to parenting styles. The style of parenting is the resultant of ways and methods of influencing a child, which determines the quantity and quality of various interactions with a child. The parenting style is largely influenced by the experiences of parents from the family home as well as external factors. J. Mariański lists four styles of upbringing: indifferent, naive (in two dimensions), paradoxical. Indifferent style occurs when parents do not put any requirements on the child, as well as unrestricted emotional support in the family. The naive style (in the first dimension) is characterized by the resignation of parents' requirements for the child but they show emotional commitment and strive to create a warm atmosphere in the family. The paradoxical style is manifested by the parents placing requirements with the simultaneous lack of ensuring the emotional climate of family life and the lack of emotional support of the child during his life. The naïve style in the second dimension is manifested by combining requirements with parents' readiness for a real dialogue with the child and 
Kazubowska, 2020. Methods of Upbringing in the Family as an Area of Forming the Upbringing Awareness of Parents on the Example of the Functioning of Professional Foster Families in Szczecin

creating personal parental warmth in the family (Mariański, 2001). In studies on the style of parenting, authors, e.g. R. White and R. Lippitt, distinguish three parenting styles: autocratic, democratic and free-hand-liberal. In addition to these styles, Hansen distinguishes a fourth style: indefinite. The indeterminacy of this style is associated with a lack of resolution and consistency in the actions of the parent (guardian) and differs qualitatively from the style of the free (liberal) hand but involving the complete non-involvement of the parent in the child's behavior (Hansen, 2012; Borecka - Biernat, 2001). Parenting styles do not often appear in pure form, they transform in line with the course of family life. It is a complex process of building ways and models of parents' interaction with children, continuing in specific family environments, entangled in a variety of factors inherent in the environment of their life understood in a narrow and broad way. Taking into account the above theoretical approaches to methods and styles of family upbringing, foster parenting methods preferred by the surveyed parents are indicated later in the text.

\section{Upbringing methods preferred in professional foster families functioning in the city of Szczecin}

In carrying out the research process, it was aimed to identify which parenting methods are preferred by foster parents in professional foster families. Interviews conducted at home allowed the researcher to make observations during their duration and to enrich the research material obtained in this way. An observation sheet was previously prepared in accordance with the research needs. Foster parents were asked to indicate which parenting methods were most important to them and asked to justify their choice. In the 28 foster families examined, all parents decided strongly that upbringing methods must be individualized, they cannot be used in a schematic way. The surveyed parents see the need to individualize the educational process for each of the children entrusted to them. Among the upbringing methods, the method of direct influence with its various implementation dimensions was most often chosen by foster parents. One of the important dimensions of this method is modeling, which the surveyed parents used in their educational work with children used by indicating specific patterns and behavior patterns in various situations at home and outside. By showing these patterns and patterns, the parents surveyed took into account the situation, age, child's experiences, and state of health. Another variant of the direct impact method indicated by the parents surveyed is setting educational tasks for children. In this case, parents pointed out in detail what type of tasks they set for children. These sentences focused mainly on daily selfservice, hygiene activities performed by children at home, cleaning up and functioning of children outside the home (e.g. in a shop, in a church, on the 
street, at the doctor's), doing homework, building relationships with animals and exercising care them. As the foster parents pointed out, often the simplest activities caused problems for children, even if they could not dress themselves or carry out simple hygiene activities (e.g. brushing teeth). As part of the direct influence method, parents also prefer the verbal educational method, i.e. persuasion. This is definitely the most frequently chosen educational method. As they say very patiently, they calmly explain, explain, justify, and argue to children why one should act in a certain way, what are the contraindications of given behaviors. Persuasive actions are always based on the values and norms they recognize, which they constantly pass on to children, aiming to make them aware of the legitimacy and sense of taking into account the principles in human life according to the stage of his development. Persuasion used in educational work with children, according to the surveyed parents, gives them the opportunity to improve their patience, control of emotions or anger, as well as teaches communication skills, clarity of expressing thoughts and specifically forces them to be open in family relationships. Equally frequently used by foster parents is the method of rewarding and punishing. As they themselves indicate, they prefer to reward rather than punish. Among the awards are those often used, i.e. symbolic awards, i.e. praise for even simple everyday activities at home, expressing approval for children's behavior or congratulating them on even minor successes. Another type of reward used by the surveyed parents are material rewards such as toys, books, school accessories, gifts, going to the cinema, theater, etc. In relation to older children, the surveyed parents use honorary rewards, i.e. allow them to perform a specific function, give certain privileges to children, stimulating them to continue to be active. An example of such a reward is even the privilege of going out with peers to a meeting or using a computer more often than usual. The surveyed foster parents have created a peculiar canon of the principles of using rewards in family education. One of these principles is the progressive increase of awards, their attractiveness, individualization, regularity, and rewarding reliance on family axiology (Górnicka, 2015). When it comes to punishments, they try to avoid them if possible, and if necessary, apply punishments adequate to the child's guilt, age, health condition and biological family experience. They avoid physical and corporal punishment, violence and aggression towards children. By using childcare punishments, they do not humiliate, offend or hurt their feelings, which means they do not measure them in a state of emotional agitation. They try to punish children without postponing this fact and explaining why they must do it. Foster parents try to individualize punishments and adapt to the dimension of the offense, as well as encourage children to make amends. When assessing the use of reward and punishment, foster parents apply them in a flexible manner, taking into account the multitude of rewards and penalties that can be 
Kazubowska, 2020. Methods of Upbringing in the Family as an Area of Forming the Upbringing Awareness of Parents on the Example of the Functioning of Professional Foster Families in Szczecin

used. Equally often, the surveyed parents use the method of personal influence, which means that they try to show children through their behavior how to behave in the right way. Foster parents also use situational impact methods in the process of upbringing, i.e. they explain in the context of a given situation regularities and irregularities in behavior. For older children, foster parents use methods of self-development management, and this is manifested by supporting, talking and making people aware of what can be done further in life so that it brings satisfaction, a sense of accomplishment and contributes to the selfimprovement of the individual.

The briefly obtained data on the preferred methods of family upbringing clearly confirm their positive, constructive dimension in the context of exercising educational and socialization processes towards children raising in family custody.

\section{Conclusions}

The analysis of the issue of parenting methods carried out in the text as an area of shaping parents 'educational awareness on the example of the functioning of professional foster families allows to indicate a direct relationship between parents' preferred methods of parenting in the family and the level of their educational awareness. In Danuta Opozda's opinion, the perceptive dimension of educational awareness is related to the integration of information about the environment perceived by the parent. These are information about the child (who he is and what value it is for the parent), about himself (his character traits, values and life aspirations), about upbringing (information about the aims, principles and educational measures used in the process of family education), about the external context educational situations (linking what happens in the family, school, local environment, media, state, society). This author draws attention to the holistic approach to educational awareness, taking into account the perceptive and introspective levels in parallel (Opozda, 2012).

The following conclusions could be drawn from the conducted research at this stage:

1) There is a direct relationship between the parenting methods used in the family by the parents and the level of their educational awareness manifested, for example, by the commitment and axiological saturation of all educational activities towards children (Kazubowska, 2019, 240-253)

2) The preferred parenting methods of the surveyed parents are positive and constructively affect the optimal development of children raised in a foster family 
3) Upbringing methods are diverse, complementary to each other and having a complementary dimension

4) In carrying out educational processes in the family, foster parents take into account the basic principles and rules of integral perception of the child and creating adequate educational interactions with him

5) Parental attitudes of the surveyed parents have a positive dimension and are conducive to the development of raised children

6) The educational impact of foster parents towards children are saturated with commitment, self-creation and have a creative dimension

7) Positive upbringing methods preferred by parents raise their level of upbringing awareness and allow them to improve their educational interactions towards children, as well as to support their holistic support.

\section{Summary}

When analyzing the specifics of the methods of family education used, it is always worth looking for their conditions focusing on various internal and external factors. Internal conditions for the selection of family upbringing methods result mainly from the experience gained from the family home, while the external ones are primarily the spectrum of a multitude of socio-cultural factors. The choice of parenting methods in the family is related to the perception of their role in the child's life and the awareness of the need to engage in an optimal way in creating the widest development plane for them (Bakiera, 2013; Wesołowska, 2019). The belief in this should accompany modern parents, that by implementing educational processes in the family they contribute to the optimal development of children, but also create a path for their self-development.

\section{References}

Bakiera, L. (2013). Zaangażowane rodzicielstwo a autokreacyjny aspekt rozwoju dorostych. Warszawa: Difin.

Borecka-Biernat, D. (2001), Zachowanie nieśmiałe młodzieży w trudnej sytuacji społecznej. Kraków: Oficyna Wydawnicza „Impuls”.

Cudak, H. (2001). Socjalizacja i wychowanie we współczesnych rodzinach polskich. Piotrków Trybunalski: Naukowe Wydawnictwo Piotrkowskie przy Filii Akademii Świętokrzyskiej.

Czerny, J. (1998). Zarys pedagogiki aksjologicznej. Katowice: "Śląsk"

Czerwińska- Jasiewicz, M. (2015). Psychologia rozwoju młodzieży w kontekście biegu ludzkiego życia. Warszawa: Difin.

Frączak, Z., \& Lulek, B. (2010). Wybrane problemy pedagogiki rodziny. Rzeszów: Wydawnictwo Uniwersytetu Rzeszowskiego.

Górnicka, B. (2015). Metodyka pracy opiekuńczo-wychowawczej: wybrane zagadnienia. Podręcznik akademicki. Opole: Wydawnictwo Uniwersytetu Opolskiego. 
Kazubowska, 2020. Methods of Upbringing in the Family as an Area of Forming the Upbringing Awareness of Parents on the Example of the Functioning of Professional Foster Families in Szczecin

Hansen, T. (2012). Parenthood and happiness: A reviev of folk theories versus empirical evidence. "Social Indicators Research”, 108(1), 29-64.

Izdebska, J. (2003). Dziecko w rodzinie $i$ w środowisku rówieśniczym: wybrane zagadnienia $i$ źródła z pedagogiki społecznej. Białystok: Trans Humana.

Jarosz, E. (2017). Rodzicielstwo z biciem w tle : między oficjalnym zakazem a rzeczywistością kar fizycznych. w: Brągiel, J., Górnicka B. (red.). Rodzicielstwo w obliczu trudności $i$ problemów życiowych oraz ich przezwyciężanie. Opole: Wydawnictwo Uniwersytetu Opolskiego

Jundziłł, I. (1986). Nagrody i kary w wychowaniu. Warszawa : Nasza Księgarnia

Kazubowska, U. (2010). Odpowiedzialność rodzicielska jako wartość. Teoria i praktyka. Toruń: Akapit

Kazubowska, U. (2017). Rodzina jako przestrzeń profesjonalnego i intuicyjnego wspierania rozwoju dziecka. w: Buława - Halasz, J. (red.). Wokół rozwoju dziecka. Szczecin: volumina.pl

Kazubowska, U. (2019). Values in the family - the specificity and transfer in the process of forming the identity of the child. Society. Integration. Education. DOI: http://dx.doi.org/10.17770/sie2019vol3.3765

Konarzewski, K. (1982). Podstawy teorii oddziaływań wychowawczych. Warszawa: PWN.

Łobocki, M. (2004). Wprowadzenie do metodologii badań pedagogicznych. Kraków: Wydawnictwo Impuls.

Łobocki, M. (2003). Metody i techniki badań pedagogicznych. Kraków: Oficyna Wydawnicza „Impuls”.

Mariański, J. (2001). Kryzys moralny czy transformacja wartości ?: studium socjologiczne. Lublin: Towarzystwo Naukowe KUL.

Opozda, D. (2012). Struktura i treść jednostkowej wiedzy o wychowaniu. Studium pedagogiczne wiedzy rodziców i jej korelatów. Lublin: Towarzystwo Naukowe KUL.

Okoń, W. (1995). Wprowadzenie do dydaktyki ogólnej. Warszawa: Wydawnictwo Akademickie Żak.

Paszkiewicz, A. (2001). Technologia wychowania. Białystok: Trans Humana.

Praszkier, R. (1992). Zmieniać nie zmieniajac: ekologia problemów rodzinnych. Warszawa:Wydawnictwa Szkolne i Pedagogiczne.

Schaffer, H.R. (2006). Psychologia dziecka. Warszawa: PWN.

Sikora, D. (2010). Nagrody i kary w wychowaniu rodzinnym a sytuacja szkolna uczniów gimnazjum. Lublin: Wydawnictwo UMCS.

von Bertalanffy, L. (1984). Ogólna teoria systemów. Warszawa: PWN.

Wesołowska, P. (2019). Świadomość pedagogiczna wspótczesnych rodziców oraz jej źródła. Poznań: Wydawnictwo UAM.

Ziemska, M. (1973). Postawy rodzicielskie. Warszawa: Wiedza Powszechna.

Ziółkowska, A.M. (2005). Kary i nagrody. Psychologia w szkole, 2. 